\title{
公立青年の家の施設利用に関する研究 $(2)$
}

\section{一一利用者出現率,利用者人数,利用率から見た施設配置計画の研究—}

\author{
（青年層社会教育・福祉・体育施設の研究・その 3 ）
}

正会員渡辺昭彦*

\section{§1. 研究の目的亡方法}

1. 研究の目的

地域公共施設は従来生活補導的な意味（生活困笨者や 身体障害者等に対する施設等）を強く持っていたが，生 活水準の全体的な向上等によって近年それに変化が見ら れ，一般住民が利用する公共施設も多種，多地域に設け られる事が多くなった。これに対してそれらの多様な施 設の現状の使われ方を整理し現状のあるいは今後建設さ れる施設の資料を得ること，およびそれらの施設をどの 様な観点に立って今後の施設を設立する地域の選択, 建 設順序の決定を行なえば良いかについての方法論等は現 在各種検討されている段階と言える。本報告は前報告 「公立青年の家の施設利用に関する研究(1)」に続くもの で前報告に括いて主に施設の使われ方を中心に報告し， 本報告において施設を設立する地域の選択のための方法 論についての検討を行なう。その1つの方法として施設 が設置された場合に施設を利用する利用者の出現率, 利 用者人数，利用率について着目し，利用者出現率がなる ベく均等化する，利用者人数が最大化する，利用者が高 率化するような施設位置を求め, そこに施設を立地させ る計画論を考えた。本報告では利用者出現率の均等化に ついては実際の施設の利用者出現率の分析，および複数 の施設の設置によって利用者出現率が均等化されている 例によって分析する。利用者人数の最大化については実 際の施設の例によってではそれぞれの施設に特性があっ て一概に言うことは難かしいため施設のモデルを想定す ることによってモデル計算を行ない立地位置の検討を行 なら。利用者の高率化については実際の施設の利用者の 分析によって立地位置の検討を行なう。

\section{2. 研究の方法}

施設を利用する利用者の出現率については公立青年の 家の保存質料より利用者の住所を調查し，これを青年の 家までの直線距離別に利用者人数を整理し，その結果に 調査可能であった日数を割った数字をかけて年間の直線 距離別の利用者人数とした。これを直線距離別の人口（昭

* 東京都立大学院博士課程

（昭和 47 年 4 月 10 日本稿受理 ・討論期限昭和 48 年 1 月末日）
和 40 年, 45 年の国調から 13 30 才の階層人口を求め, それを地図にプロットし直線距離別に区分したもので， 本報告では昭和 40 年国調により作業したもののみを掲 載した）で割り，直線距離別の $13 \sim 30$ 才の青年階層人 口 1 人当りが年間に 利用する確率を計算したものであ る。利用者人数については階層人口は人口中心を中心と して凸状になっていると想定し，利用者出現率も施設を 中心に凸状になると想定され，その重ね合わせる位置に よって利用者人数の增減がおこると考え，その立地位置 の検討のための面積モデル, 人口密度モデル, 利用者出 現率モデルを想定することによって各立地位置の利用者 人数を算定する。利用率については利用率は各施設の定 員は決め方がまちまちで定員を越して利用させる場合む みられるのでそれを補正して次の様に考えた。

年間の利用者人数

$$
\begin{aligned}
& \text { 定員 } \times \frac{\text { 定員 } 1 \text { 人当り均定員 } 1 \text { 人当り積 }}{} \times \text { 開所日数 } \\
& \quad \times 100=\text { 利用率 }
\end{aligned}
$$

これによって現状の各施設の利用率を計算し，立地位 㯰をからめて分析することによって利用率の高い施設位 置の検討を行なら。

\section{3. 調查の方法と時期}

調查は昭和 43 年 8 月に全国の公立青年の家 118 施設 に施設概要を郵送によるアンケート調查より求め, 昭和 43 年 9 月に上記より選択した 全国の 18 施設にインタ ヴュ一調查を行ない，公立青年の家の保存データーによ り利用内容, 利用率, 利用者住所を調 ん゙た。更に昭和 46 年 9 月に全国の公立青年の家 201 施設に土地の入手 や建設の過程についてのアンケート調查を行ない，上記 より選択した関東地方の 5 施設にインタヴュー調査を行 なった。

\section{§2. 利用者出現率から見た施設位置の検討}

1. 各施設の利用者出現率

現状の各施設の 利用者出現率を見ると図一1 3 の如 く示せ, 図一1 の岩手県久慈, 但馬文教府青年の家は日 帰り研修中心施設（両施設とも宿泊部門があるが日帰り 研修の利用が多い)で他の施設に比して利用者出現率が 


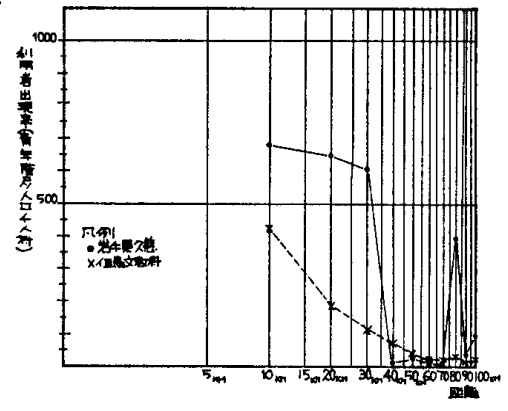

图-1直線距離別利用者出現率 (タイプA)

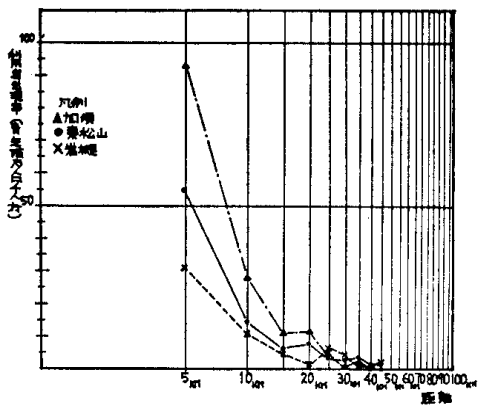

图一2 直線距離別利用者出現率 (タイブB)

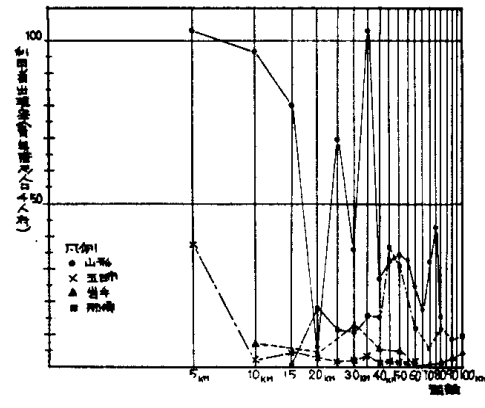

図-3 直線路離別利用者出現率 (タイプC)
高く, 他の施設の 10 倍程度となっている。図一2 の加 須, 東松山, 岩柣の青年の家は県の設置であるが地域を 対象に設置している地域施設の典型的な例と考えられ， 施設に近い部分が最も利用者出現率が高く, かつ利用者 出現率の低下が急である。また施設からの距離が遠くな るにつれて低減する。各施設の利用者出現率の相違は規 模等はほぼ同様で加須がプールを保有していることを除 いて質的にも類似している事から研修内容, 運営方法等 によると考えられる（埼玉県の各施設はそれぞれ独自の 研修の課題を持ち加須は家庭電化を課題として婦人等を 広く研修している。東松山は体育・レクリエーションを 課題とし，岩㚘は農業実習を課題としている)。図一3の 山形, 五日市, 岩手, 那須青年の家は県立, または都立 の各種の状況のもとに設置されている広域施設で, 那須 の様に山にあるため施設近辺には人口が存在せず一般的 には利用者出現率の最も高い部分がないもの, 五日市の 様に広域の施設として設けられているが立地位置により 実際の利用は地域施設化している施設, 山形の様に他の 施設に比して大規模で広域施設の中では利用者出現率の 高い施設, 岩手の様に農業青年を中心に研修を行なって おり利用者出現率の低い施設等多様である。またこれら 広域の施設は人口の分布等により利用者出現率も他の施 設に比して一様には低減しない施設が多い。以上の様に 利用者出現率は示せ,一般的には利用者出現率は距離に 反比例，または距離の 2 乘に反比例（病院の例であるが

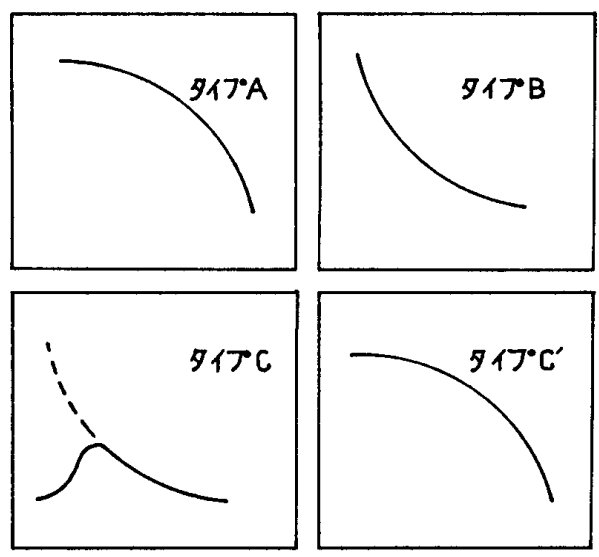

因一4 利用者出現率のタイブ
額田氏らの京都府立医大付属病院の外来初診患者の調査 においては距離に反比例することが報告されている)す るものと言え，おおむね日帰り研修中心施設が距離に反 比例, 宿泊研修中心施設は距離の 2 乗に反比例している 例が多い。さらに各施設の利用者出現率の曲線の形を整 理すると図一4の様に 4 つのタイプに整理でき，タイプ $\mathrm{A}$ が日帰り研修中心施設で久慈, 兵庫県 但馬文教府の 例, タイプ Bが公立青年の家の一般的な例で東松山, 加 須, 岩㚘で県が各市に設置し地域に関連をもたせて運営 している例, および広域施設として設けたが地域化して いる五日市の例, タイプC

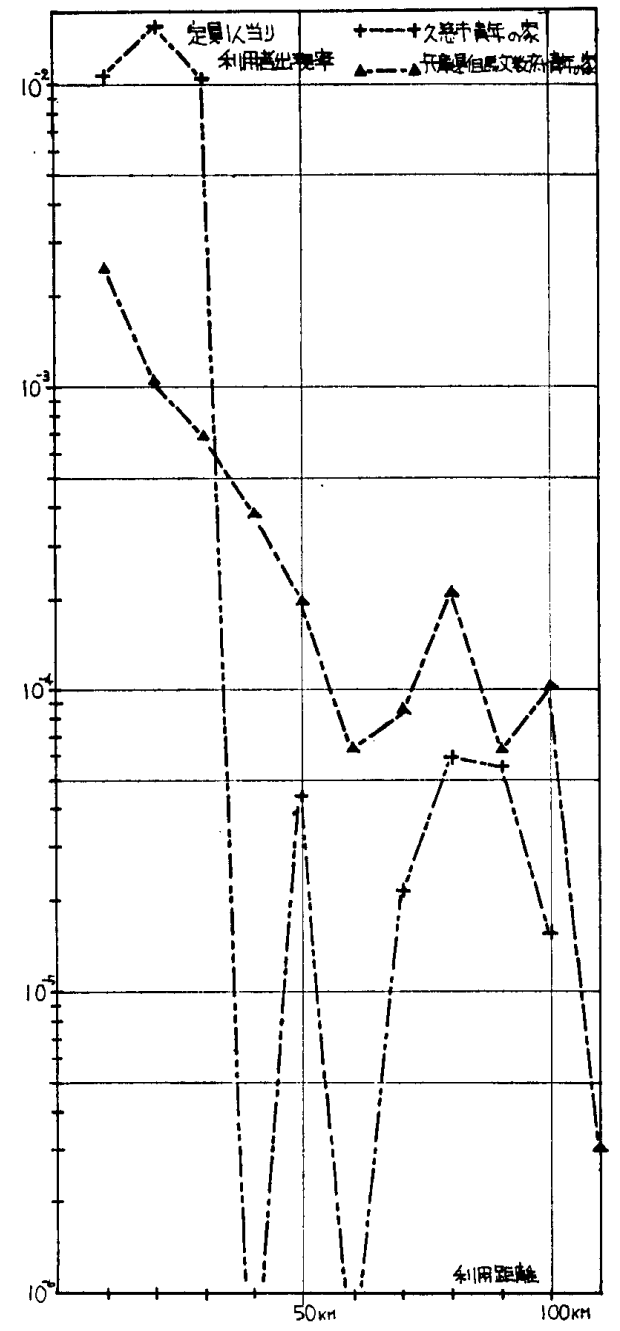

図一5 日帰り研修中心施設の定員 1 人当り利用者出現事 


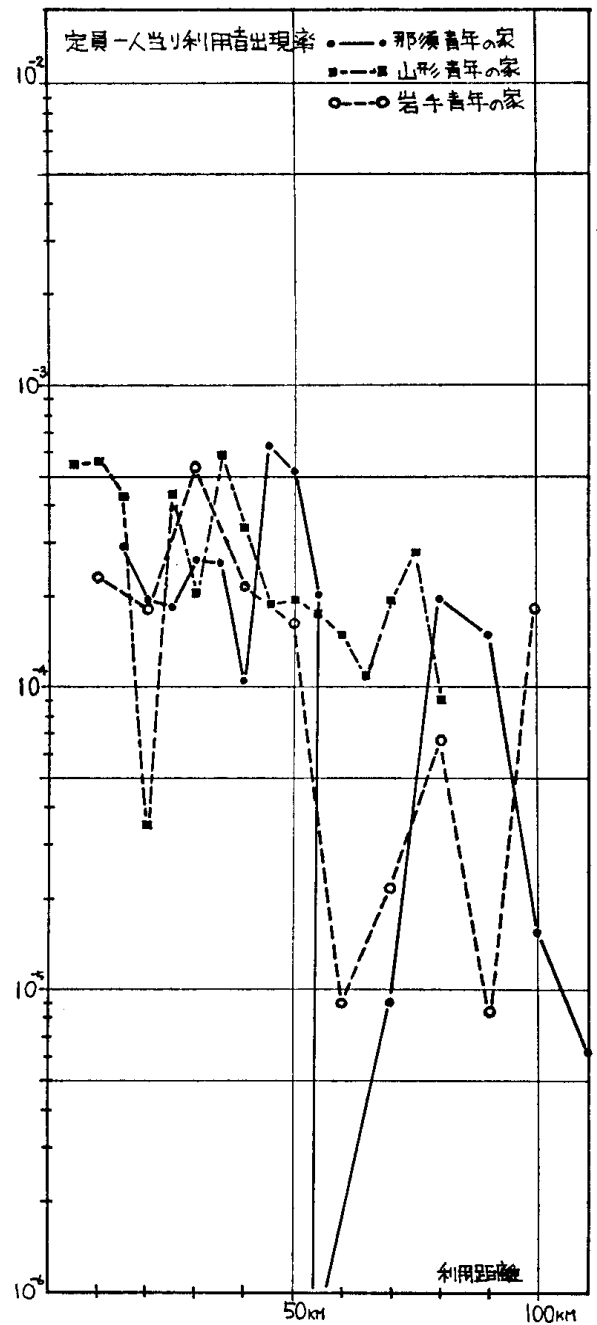

图一6広域施設の定員 1 人当り利用者出現率

め点線の部分の利用者がない岩手，那須の例，タイプ $\mathrm{C}^{\prime}$ は一般的には利用者出現率が急減する距離の部分が人口 のピークで，その部分の利用者が多いため利用者出現率 が凸状となっている山形の例である。この様に各施設の 利用者出現率は施設からの階層人口の分布の状態により

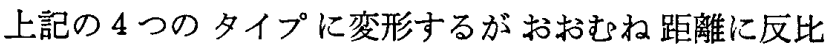
例，または距離の 2 乗に反比例すると言え，本来公共施 設としてなるべく利用機会を均等化させることが望まし いにもかかわらずこの様な差が生じている。上記の施設 の中では比較的広域施設が均等化に近いと言えるが，こ れはやはり広域施設として施設から離れた距離の人達も 利用する様な運営が行なわれる事や，距離が離れた人達 も利用したくなるような代表的な景勝地等に立地する等 が若干均等化をもたらしている理由と言えよう。また日 韧り研修中心施設も利用者出現率が急減している部分も あるが全般には低減が少なく，研修型態によっても均等 化を計れると言えよう。

2. 定員 1 人当り利用者出現率

前述の利用者出現率は施設全体としての比較を行なっ たが各施設の定員には差があるため前述の利用者出現率 を補正した施設定員（各施設の定員 1 人当り面積/平均

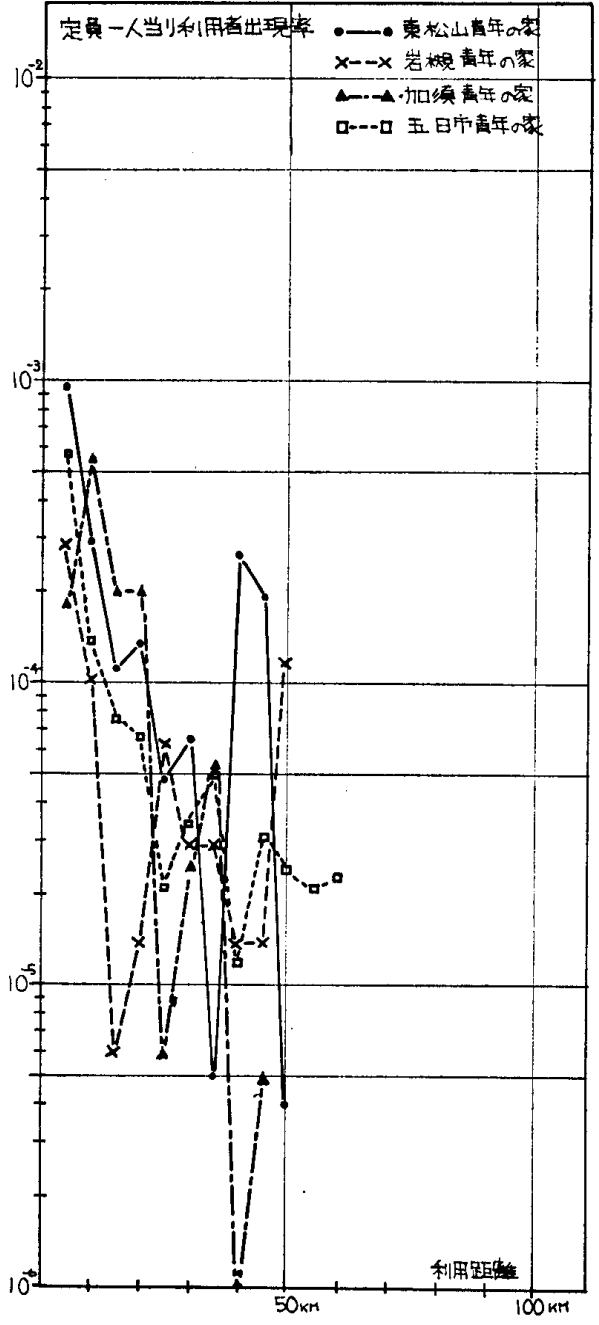

図一7地域施設の定員 1 人当り利用者出現率

定員 1 人当り面積をかけたもの）で割り定員 1 人当り利 用者出現率を見ると図一5 図一7 の様に広域施設と地 域施設とは更に明確に分かれ，広域施設同士，地域施設 同士では類似してくる。つまり利用形態，運営形態によ る影響は大きいが一般的には広域施設，地域施設とも施 設定員が増加すれば利用者出現率も増加すると言える。

3. 利用者出現率と利用距離, 利用者累積比率

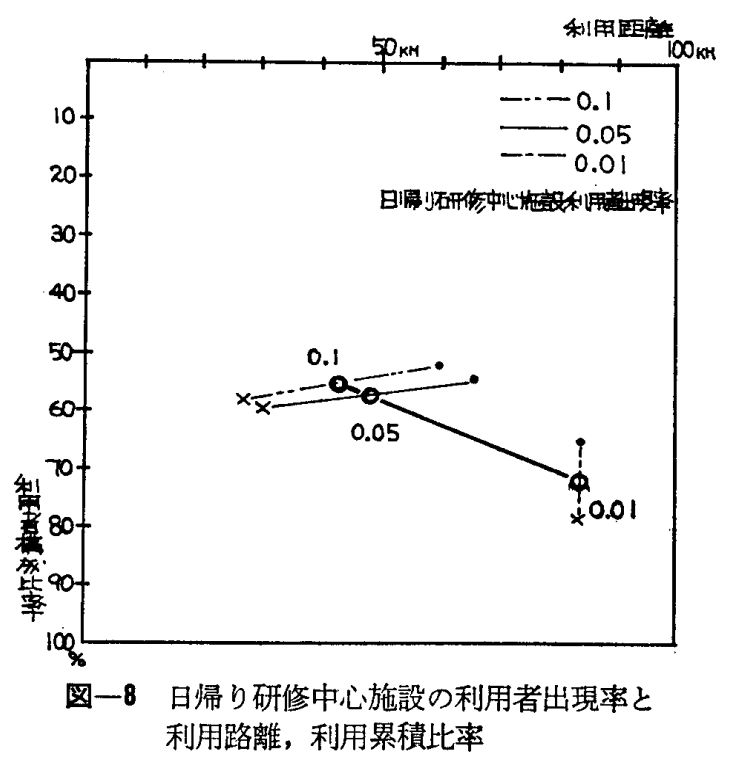


・各施設タイプ別に利用者出現率と利用距離, 利用者累 積比率の関連を見ると日帰り研修中心施設は図一8, 地 域施設は図一9, 広域施設は図一10 の様に示せる。これ を見ると日帰り研修中心施設は利用者出現率が 0.1 0.05 の人達が少なく, 全般に出現率の低下がゆるやか であることが分る。また従来 $50 \%$ 距離といっていた人 達は 0.1 以上で, $75 \%$ 距離は 0.01 以下の人達であ

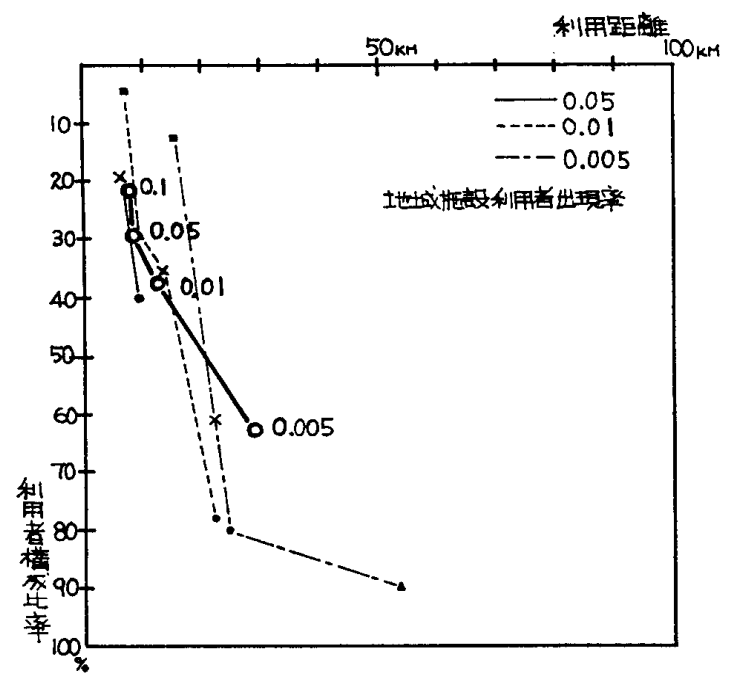

図一9 地域施設の利用者出現率と利用距離, 利用者累積比率
る。地域施設は利用者出現率の 低下が最も急で， $25 \%$ 距離の人達は利用者出現率が $0.01 \sim 0.05,50 \%$ 距離の 人達は $0.001 \sim 0.0005$ である。広域施設は平均的には 約 $40 \%$ の人達が $20 \mathrm{~km}$ 程度から利用しており利用者 出現率が 0.1 の状態で，ほぼ $20 \mathrm{~km}$ ごとに 0.1 $0.05,0.05 \sim 0.01$ と低減している。また従来 $25 \%$ 距離 というのは利用者出現率 0.1 以上, $50 \%$ 距離は $0.1 \sim$

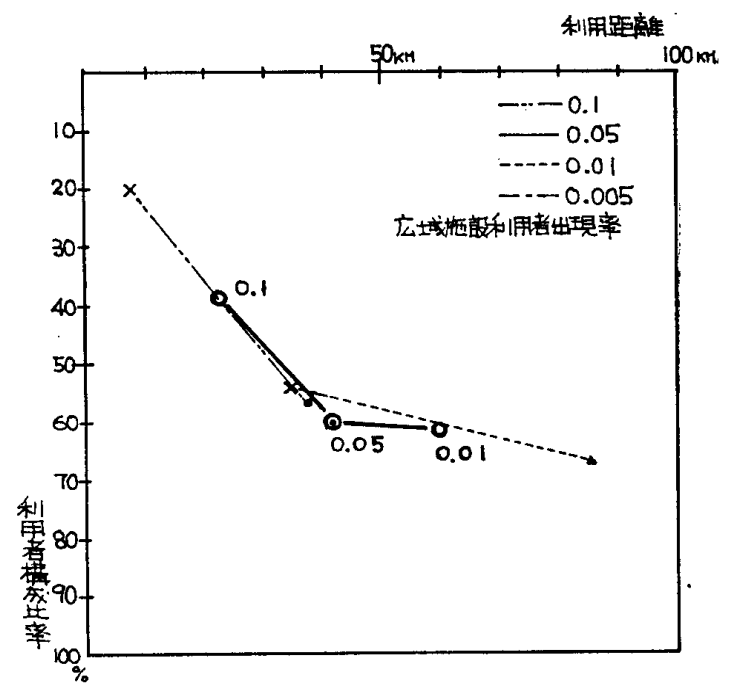

図一10広域施設の利用者出現率と利用距離，利用者累積比率

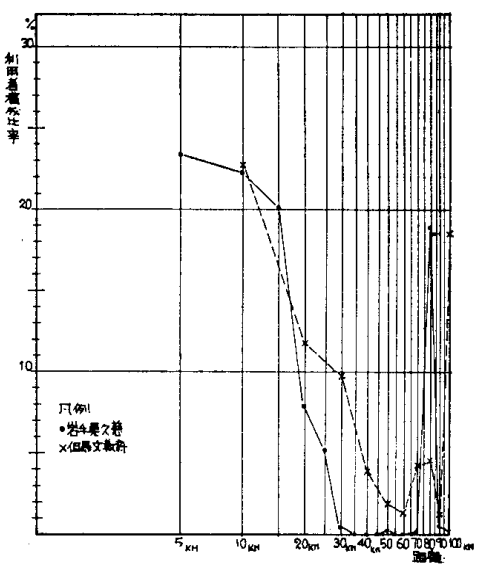

図一11 日㷌り研修中心施設の 利用者構成比率

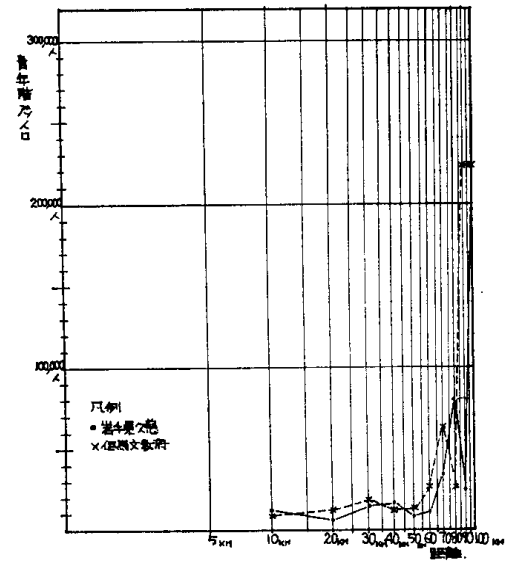

図一14 日帰り研修中心施設の 青年階層人口

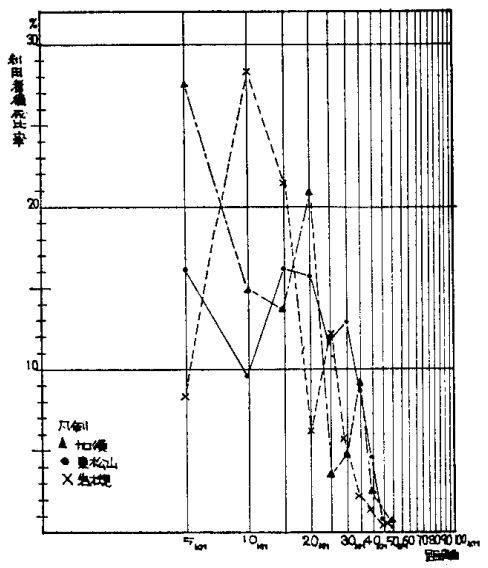

図一12 地域施設の利用者構成比率

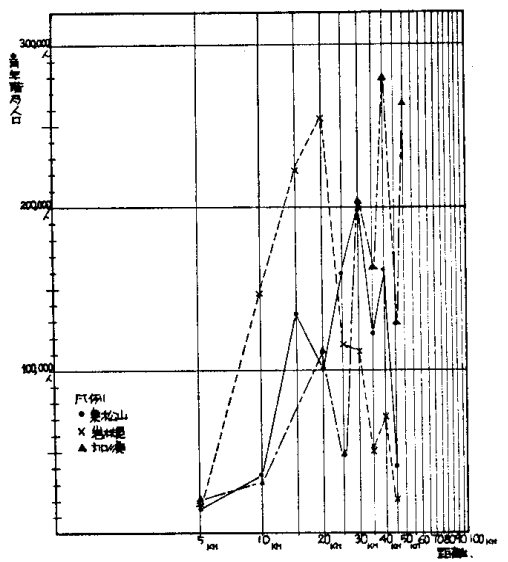

図一15地域施設の青年階層人口

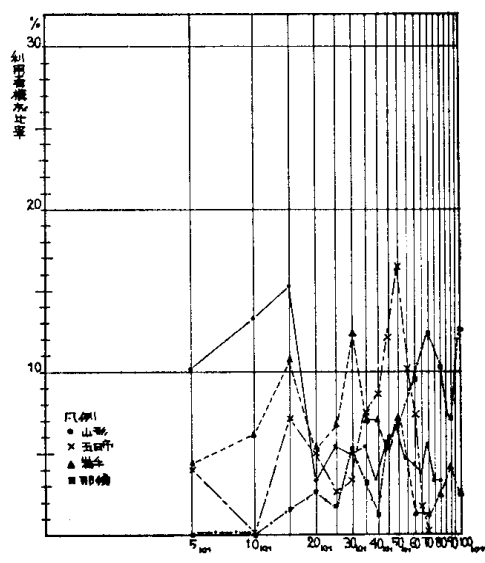

图一13広域施設の利用者構成比率

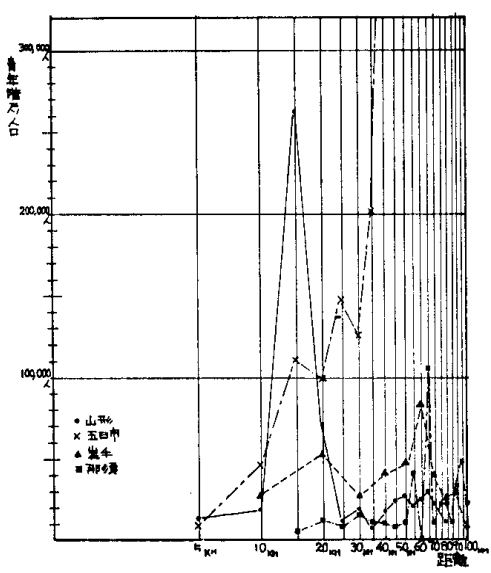

図一13 広域施設の青年階層人口 
0.05, 75\% 距離は 0.01 以下である。以上の様にこの 図により想定する利用圈域によって周辺にどの位の利用 者出現率の不均等が起るかが明確である。

4. 施設タイプと利用者構成比率, 階層人口

各施設タイプと利用者構成比率の関連を見ると図一11 〜図一13 の様に日帰り研修中心施設はいずれも施設の 近くに利用者構成比率のピークがあり, 地域施設も若干 それよりは施設から離れるが比較的近い所にピークがあ り，広域施設がピークの位置が最も多様である。これを 階層人口の図一14 図一16 と関連させて見ると日帰り 研修中心施設, 地域施設では人口がそれほど周辺で多く なくても利用者構成比率のピークは周辺にある（日帰り 研修中心施設はかなり離れた所にも構成比率の高い部分 があるが人口に較べるとわずかである）様に日帰り研修 中心施設, 地域施設の利用機会の不均等は利用者構成比 率と階層人口の関連を見ても明らかである。

5. 複数の施設による利用者出現率の均等化

各施設の利用者出現率の分析を行なってきたが単独の 施設によってでは利用者出現率の均等化には限界があ り，複数の施設の設置によって均等化を計る 必要があ る。そこで前記の例の中から同じ県内に隣接して設けら れている埼玉県の 6 施設のうち 3 施設である加須, 東松 山, 岩槻について複数施設の設置による均等化の状況を

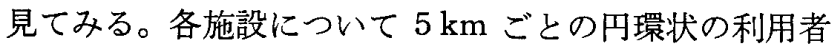
出現率をそれぞれの施設の立地している位置を中心に書 き， 3 施設の利用者出現率をたしたものを示すと図一17 の様になり，各地域における利用者出現率のかたよりが

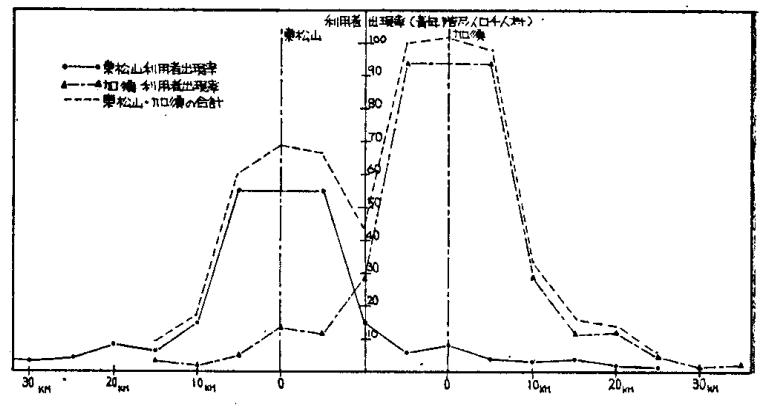

図一18 加須一東松山断面の利用者出現率

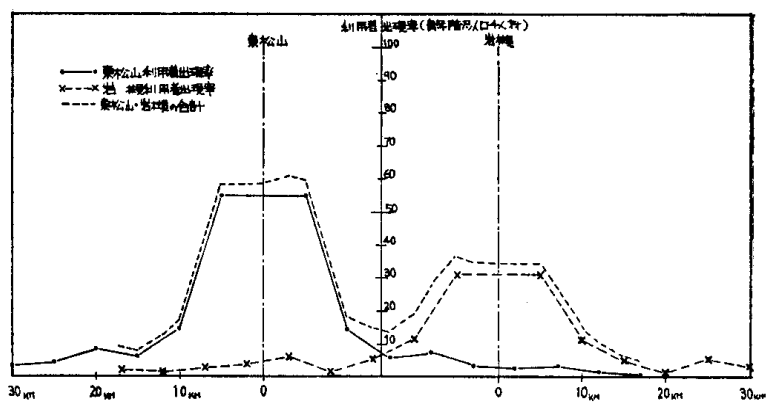

図一19 東松山一岩槻断面の利用者出現率

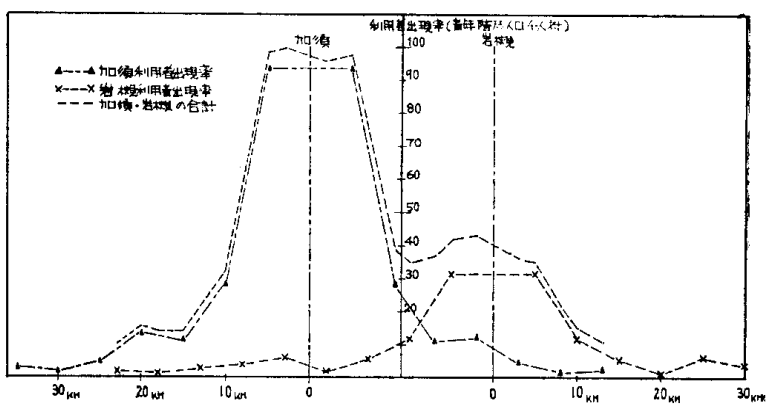

図一20 岩槻一加須断面の利用者出現率

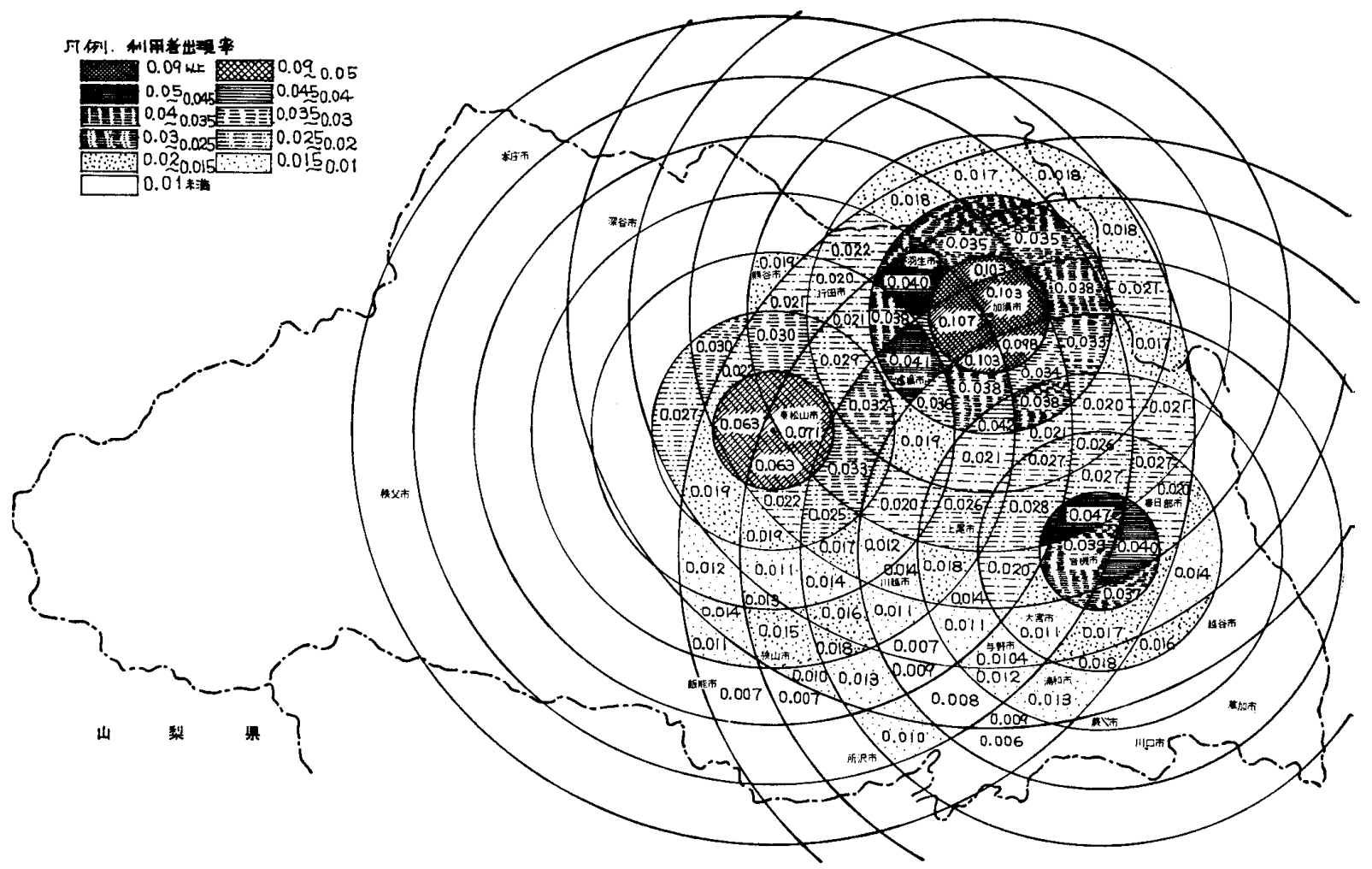

図一17埼玉県加須, 東松山, 岩槻周辺の利用者出現率 
明瞭で今後の施設設置の参考になる。

更にそのかたよりを断面によってみるために断面を示 している図一2 を各施設間の距離をとって 2 施設ずつ重 ねてみると図一18〜図一20 の様になる。これを見ると 施設間距離が約 $20 \mathrm{~km}$ である 加須一東松山, 岩槻一加 須の断面では施設の間の部分が比較的均等化されてい る。これに較べて 施設間距離が約 $30 \mathrm{~km}$ である東松山 一岩槻の断面では施設の間の部分の利用者出現率の低下 が目立つ。この3 断面から判断した限りでは施設間距離 は $20 \mathrm{~km}$ 程度なら施設間の低減する部分は少なく, 均 等化に近いと言える。この 3 施設の比較において施設間 の距離より施設による利用者出現率の差が大きく, 施設 内容等によりそれを改善していくことも重要な課題と言 えよう。

\section{§3. 利用者人数から見た施設位置の検討}

利用者人数を分析する場合一般論として施設をどの様 な位置に立地させ，その立地された位置によってどの様 に利用者人数が変化するかについてはそれぞれの施設に 特性があって一概に言う ことは難かしい。そのた め施設のモデルを想定し 人口との関連のみに限定 して施設の位置検討を行 な5。利用者人数の計算 のための想定としては図 -21 の様に立地位置検 討のための面積モデル， 人口密度モデル, 利用者 出現率のモデルを想定 し, 面積モデルに人口密 度モデルをかけて階層人 口を求め, 更に利用者出 現率モデルをかけて利用 者人数を算出する。また 利用者人数に対応した施 設規模の算定は利用者人

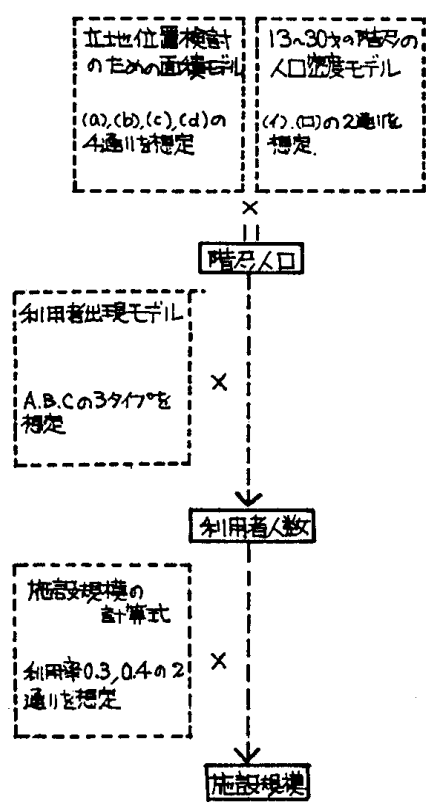

図一21 利用者人数計算のため のフローチャート
数に更に利用率を想定して前出の利用率の計算式を変形 して施設規模 $=$ 定員 $\times$ 定員 1 人当り面積 $=$ 利用者人数 $\times$ 平均定員 1 人当り面積 $\div$ (利用率 $/ 100 \times$ 開所日数) とし て計算する。

\section{1. 各種モデルの想定}

人口密度は前掲の埼玉県の東松山, 加須, 岩槻の青年 の家の地域の人口密度を参考に昭和 40 年度国調により 13 30 才の青年階層人口密度 モデルを想定し, 人口中 心から等差で減少するモデルを図一22 の（1）の様に考 え, 人口中心の人口密度がそれの倍の場合を（2）の様 に考えた。

利用者出現率は各施設の利用者出現率を参考に図一23

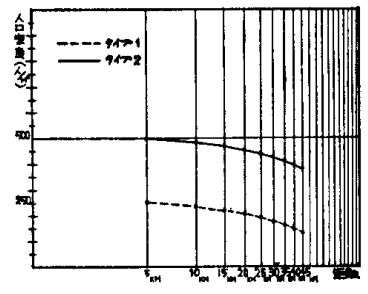

図一22人口中心からの距離 と人口密度の想定

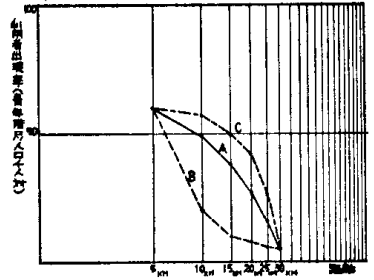

図一23施設中心からの距離と 利用者出現率の想定
の3つのタイプを想定, Aタイプは等差で減少, B夕イ プは前記埼玉県の 3 施設の例を参考に作成, Cタイプは 山形の例を参考に形の特徴を抽出して A, B タイプに合 わせて作成した。

立地位置検討の面積モデルは図一24の様に（a）人口 中心と施設位置が一致しているもの，(b)人口中心と施 設位置が $10 \mathrm{~km}$ 離れている。(c)人口中心と施設位置 が $20 \mathrm{~km}$ 離れている。(d)人口中心と施設位置が 30 $\mathrm{km}$ 離れている，の4つのタイプを想定し, 人口密度の 円環を施設からの利用者出現率の円環によってかこまれ た各部分の面積をプラニメーターで測定し, それに人口 密度をかけて人口を算出, 更に利用者出現率をかけて各 部分の利用者数を出し, それを総計してその立地位置に おける利用者人数とする。なお利用者の計算は施設中心 から $30 \mathrm{~km}$ 以内のみを行なった。
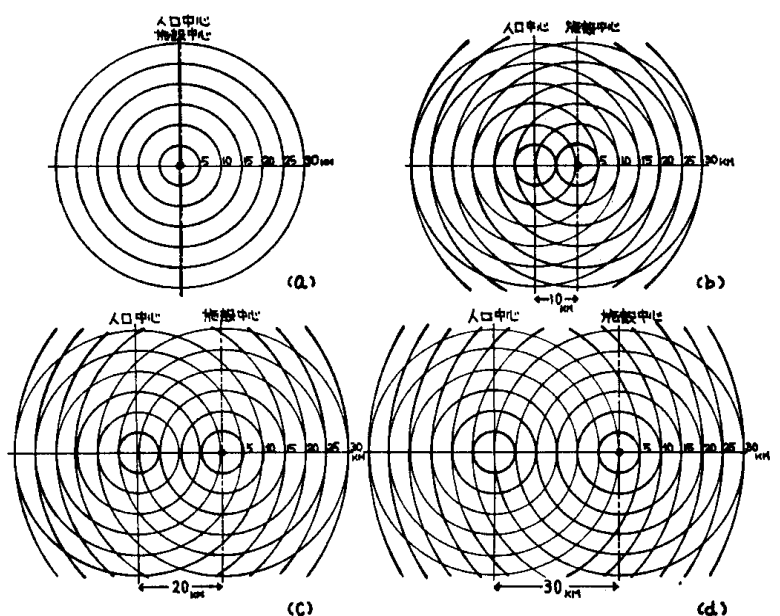

図一24 立地位置検討のための面積モデル

施設規模については前述の様に施設規模 $=$ 定員 $\times$ 定員 1 人当り面積 $=$ 利用者人数 $\times$ 平均定員 1 人当り面積 $\div$ (利用率 $/ 100 \times$ 開所日数) とし, 平均定員 1 人当り面積 は昭和 45 年度時点における面積を使い，それは施設規 模の拡大とともに若干増加しているが全体の平均 15.35 $\mathrm{m}^{2}$ を使った。なを開所日数, 利用者については開所日 数は平均開所日数 300 日を使用し，利用者は平均的な利 用率の 30\%，若干高目である $40 \%$ を使用した。

\section{2. 上記の各種モデルによる計算}

上記の各モデルを使って次の様なモデル計算を行な 5。（イ）人口密度タイプ 1 の場合で利用者出現率タイ 


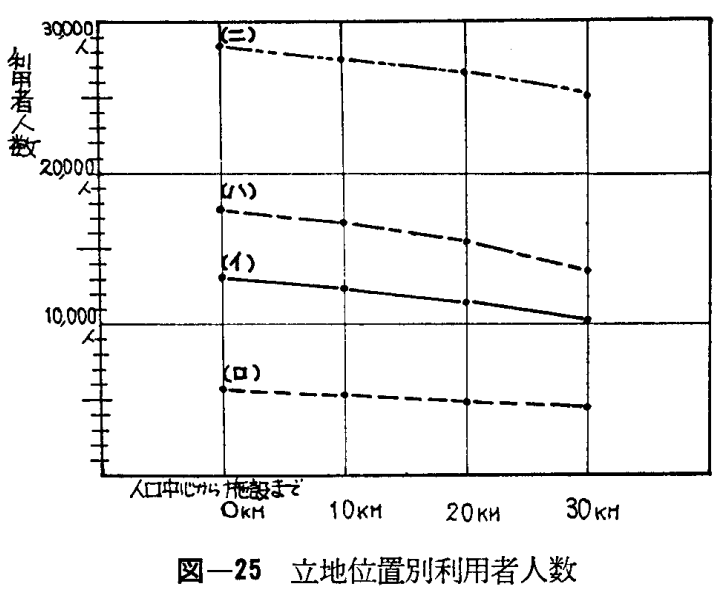

プAの場合の各立地位置における利用者人数を計算す る。(口) 同じく人口密度タイプ1の場合で利用者出現 率タイプ $\mathrm{B}$ の場合の各立地位置における利用者人数を計 算する。(八) 同じく人口密度 タイプ1 の場合で利用者 出現率タイプ $\mathrm{C} の$ 場合の各立地位圆における利用者人数 を計算する。（二）人口密度タイプ 2 の場合で利用者出 現率タイプAの場合の各立地位置における利用者人数を 計算する。以上の 4 つのケースについての計算を行ない その結果を示すと図一25 の様に示せ，各想定による利 用者人数の差はあるが，どの想定においても立地位置検 討の面積モデル（a）の人口中心と施設位置が一致して いる場合，つまり施設を人口中心に置いた場合が最も利 用者人数が最大化し，人口中心から施設までの距離が離 れるにしたがって低減している。その低減を各ケース別 に比率でみると表一1 の様に示せ。人口密度タイプ1の 3 つのケースでは人口中心に施設を位置させた場合に対 して人口中心から $10 \mathrm{~km}$ 離れると $5 \sim 7 \%$ 利用者人数 が減少し，人口中心から $20 \mathrm{~km}$ 離れると $12 \%$ 減少し， 人口中心から $30 \mathrm{~km}$ 離れると $23 \%$ 減少する 様に人口 中心から離れる程利用者人数の減少が大きくなり，その 低減の比率は人口密度が同じなら利用者出現率は異なっ てもほとんど変わらない。人口密度タイプ2のケースで は人口中心に施設を位置させた場合に対して人口中心か ら $10 \mathrm{~km}$ 離れると $3 \%$ 利用者人数が減少し, 人口中心 から $20 \mathrm{~km}$ 離れれると 6\%，人口中心から $30 \mathrm{~km}$ 離れ

表一1 各ケースにおける利用者人数と比率

\begin{tabular}{|c|c|c|c|c|}
\hline 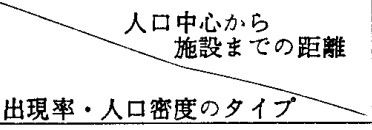 & $\begin{array}{l}\text { 人口中心 } \\
\text { から施設 } \\
\text { まで } \\
0 \mathrm{~km}\end{array}$ & $\begin{array}{l}\text { 人口中心 } \\
\text { から施設 } \\
\text { まで } \\
10 \mathrm{~km}\end{array}$ & $\begin{array}{l}\text { 人口中心 } \\
\text { から施設 } \\
\text { まで } \\
20 \mathrm{~km}\end{array}$ & $\begin{array}{l}\text { 人口中心 } \\
\text { から施設 } \\
\text { まで } \\
30 \mathrm{~km}\end{array}$ \\
\hline 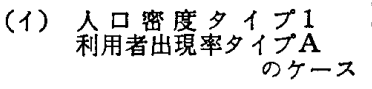 & $\begin{array}{r}1311 \text { 人 } \\
100 \%\end{array}$ & $\begin{array}{c}1246 人 \\
95.03 \%\end{array}$ & $\begin{array}{c}11516 \text { 人 } \\
87.8 \%\end{array}$ & $\begin{array}{l}10069 人 \\
76.8 \%\end{array}$ \\
\hline $\begin{array}{l}\text { (ロ) 只密度タイプ1 } \\
\text { 利用者出現率タイプB } \\
\text { のケース }\end{array}$ & $\begin{array}{c}5610 人 \\
100 \%\end{array}$ & $\begin{array}{l}5228 \text { 人 } \\
93.2 \%\end{array}$ & $\begin{array}{l}4935 \text { 人 } \\
88.0 \%\end{array}$ & $\begin{array}{l}4316 \text { 人 } \\
76.9 \%\end{array}$ \\
\hline 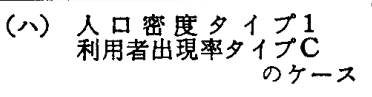 & $\begin{array}{c}17626 \text { 人 } \\
100 \%\end{array}$ & $\begin{array}{c}16866 \text { 人 } \\
95.5 \%\end{array}$ & $\begin{array}{c}15587 人 \\
88.4 \%\end{array}$ & $\begin{array}{l}13594 \text { 人 } \\
77.1 \%\end{array}$ \\
\hline 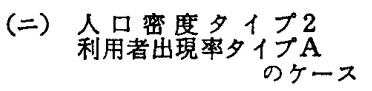 & $\begin{array}{c}28521 \text { 人 } \\
100 \%\end{array}$ & $\begin{array}{c}27703 \text { 人 } \\
97.1 \%\end{array}$ & $\begin{array}{c}26831 \text { 人 } \\
94.1 \%\end{array}$ & $\begin{array}{l}25214 \text { 人 } \\
88.4 \%\end{array}$ \\
\hline
\end{tabular}

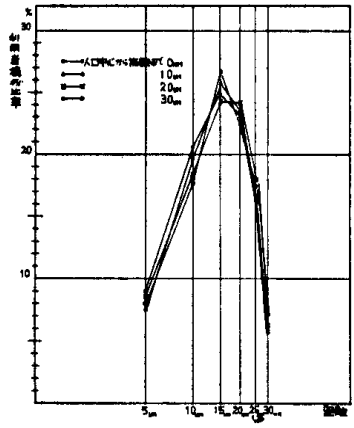

図一26(イ)

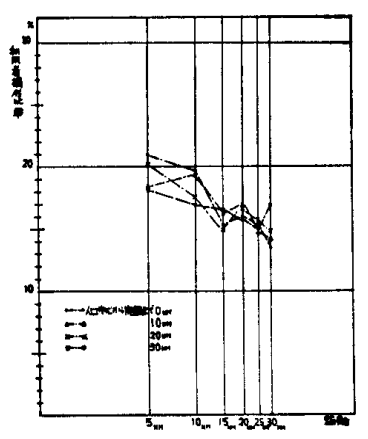

图-26 (二)

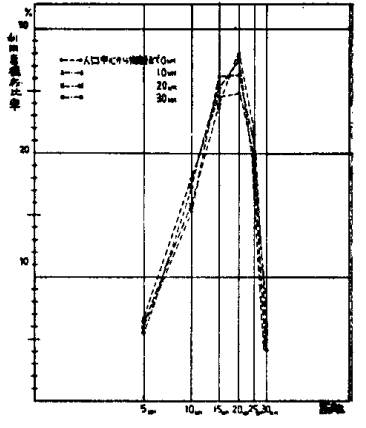

图一26( (F)

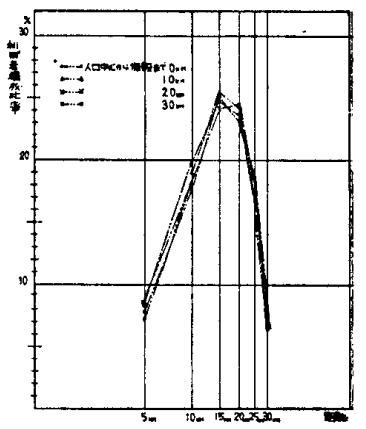

图-26(八)
図一26 立地位置別利用者構成比率

ると $12 \%$ 程度減少し, 人口密度タイプ1よりは少ない が人口中心から離れる程利用者人数の減少が大きくなる 傾向がある。

人口密度タイプ 1 の場合の利用者出現率タイプ $\mathrm{A}, \mathrm{B}$ ， $\mathrm{C}$ の利用者人数の比較を行なうと当然ながら利用者出現 率の高い順の $\mathrm{C}, \mathrm{A}, \mathrm{B}$ の順になっていて, 利用者出現 率のタイプ $\mathrm{B}$ に比較してタイプAの場合は 2 倍以上，夕 イプ $\mathrm{C}$ の場合は 3 倍以上の利用者人数となっている。利 用者出現率タイプAの場合の人口密度タイプ 1 と 2 の比 較を行なうとタイプ 2 が 1.3 倍利用者が多い。これは タイプ1 と 2 の人口密度差ほどは利用者人数は増加しな いことを示している。次に各ケースに括ける利用者構成 比率を見ると図一26（イ），(口)，(八)，(二）の如くな り，(イ，（口)，(二)のケースでは 15 20 km 地点が 最も利用者の多い地点で，(八）のケースでは施設に近 い $5 \mathrm{~km}$ 地点が最も利用者の多い地点となっている。 これは利用者出現率が凸状になるとそれだけ距離が効き 施設周辺の利用者が多くなるためである。

3. 利用者人数からの施設規模の計算

前記の人口密度, 利用者出現率, 施設立地位置の検討 のための面積モデルによる各立地位置の利用者人数を施 設規模の計算式に代入し, 平均定員 1 人当り面積 15.13 $\mathrm{m}^{2}$, 開所日数は平均開所日数 300 日, 利用率は平均的な 利用率の $30 \%$ ，若干高目である $40 \%$ を想定して計算を 行ならと利用率 $30 \%$ の場合は図一 27 , 利用率 $40 \%$ の 場合は図一28 の様になり，人口の分布との関連のみで 見た場合には人口中心から施設を離して設置するほど施 設規模は低減させることができる。なおこの施設規模の 


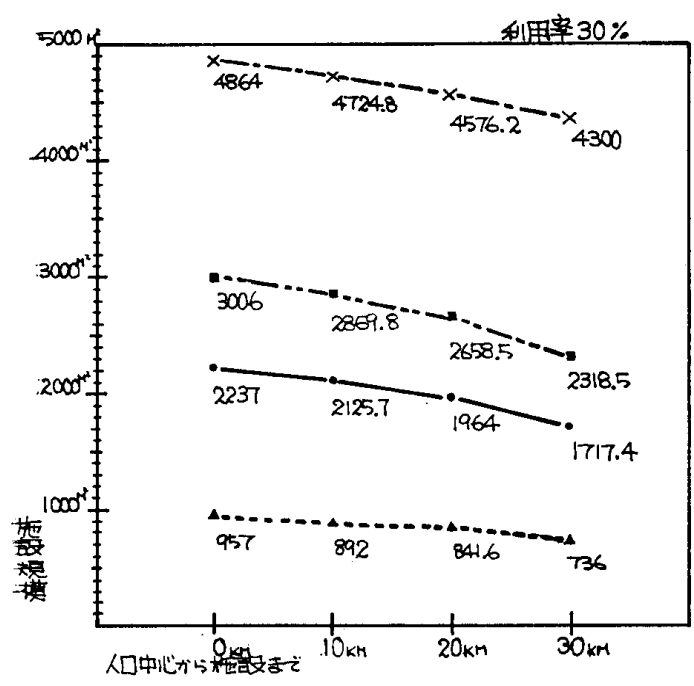

図一27利用率 30\% の場合の立地位置別施設規模

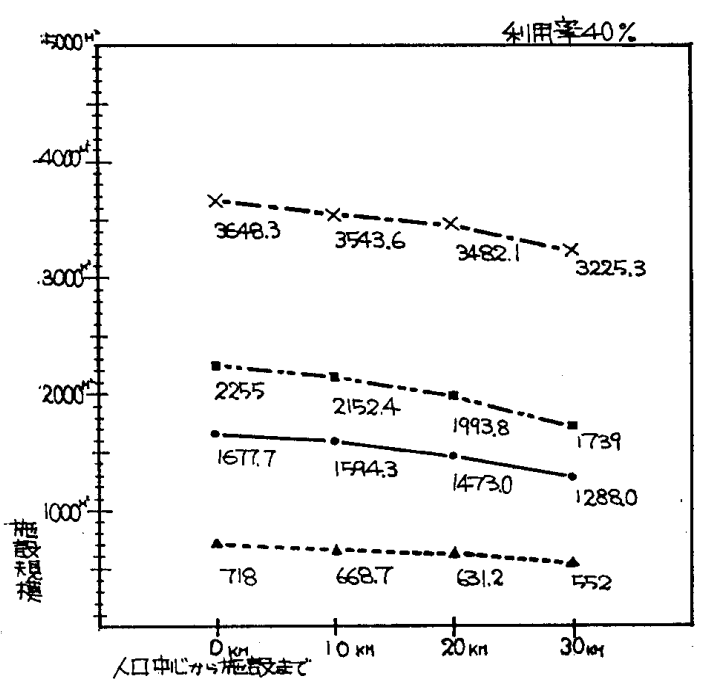

図一28 利用率 $40 \%$ の場合の立地位置別施設規模

計算では施設立地位置による施設規模の差と同様に利用 者出現率による差, 利用率による差, 人口密度による差 も大きくそれらの適確な予測が重要と言えよう。

4. 利用者人数と利用率の変化

前記のモデル計算に扔いては施設立地位置によって利 用率は変化しないと想定したが一般に景観が良い等の条 件がない場合には施設の利用率は郊外に設置される程利 用率が低減すると考えられ，利用率の低減による利用者 人数の低減を見てみる。利用率は人口中心と施設中心間 の距離によって等差で減少すると考え図一29 の様に (1) $10 \mathrm{~km}$ ごとに $5 \%$ ずつ減少する。(2) $10 \mathrm{~km}$ ごとに 10 \%ずつ減少する。の 2 通りを考えた。施設規模は 1038 $\mathrm{m}^{2}$ (公立青年の家の平均定員 67.6 人を使い，これに 平均定員 1 人当り面積の $15.35 \mathrm{~m}^{2} /$ 人 をかけて算出し た）とし，利用率とこの施設規模を施設規模の計算式に 代人して利用者人数を算出する。この結果は図一30の 様に一率に低減する。

5. 利用者人数一定の場合の利用者出現率の変化 ある一定の利用者人数を保ったまま利用者出現率の均

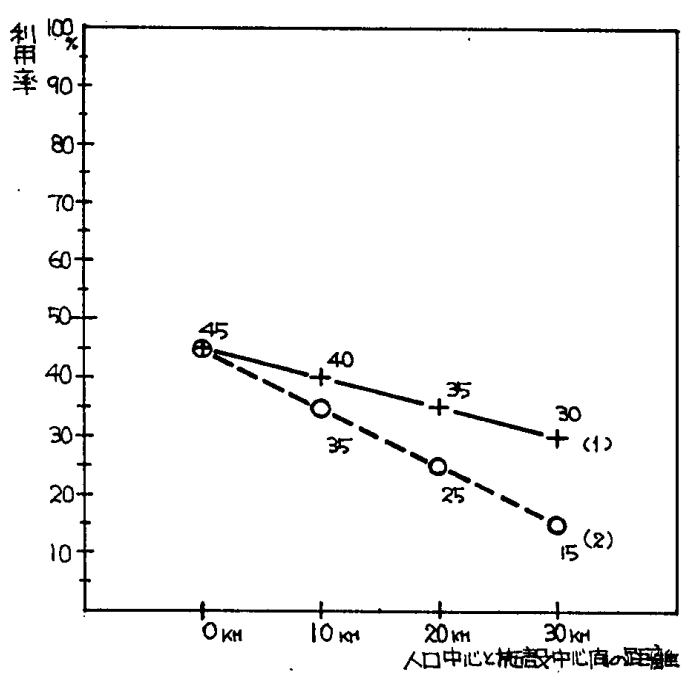

图一29 利用率の変化のモデル

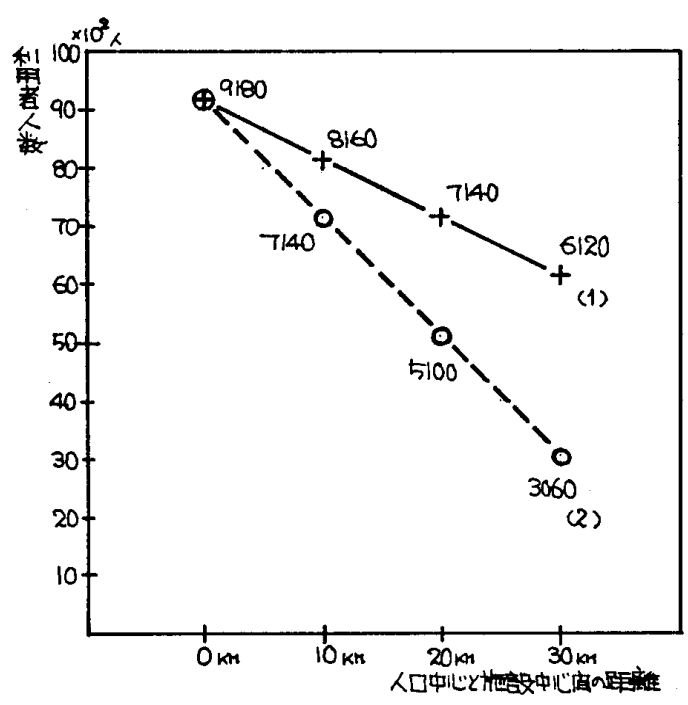

図一30 利用率を变化させた場合の利用者人数

等化を行ならにはどの様な利用者出現率がとりらるかに ついて検討する。利用者人数は前記モデル計算の中の利 用者出現率モデルAで人口密度モデル 1 の時で人口中心 に施設が立地している場合の利用者人数 13116 人を使 い，これと同じ利用者人数となる利用者出現率を求め る。また利用者出現率は性質をとらえることを目的とし て簡便な方法で直線として考えた。人口密度は前記人口 密度モデル 1 を用い, 利用者出現率は $y=-a x+b$ で与 えられるものとし ( $y$ は出現率で $x$ は施設からの距離)， $5 \mathrm{~km}$ ごとの利用者出現率, 人口密度, 円環の面積によっ て利用者入数が計算しうるものとして施設から $30 \mathrm{~km}$ までの利用者人数を計算し，それが 13116 人になるた めの $a$ と $b$ の関係を求めると $a=0.0462 b-0.00108$ と

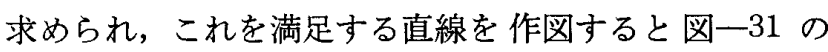
様に示せる。これを見ると当然ながら施設近辺の利用者 出現率の高さは余り利用者人数の増加に効かず施設から 離れた部分の利用者出現率が高いことが重要であること が分る。しかし現実にはその様な利用者出現率をとりう るかは問題で，あらかじめそれを考慮した運営システム 


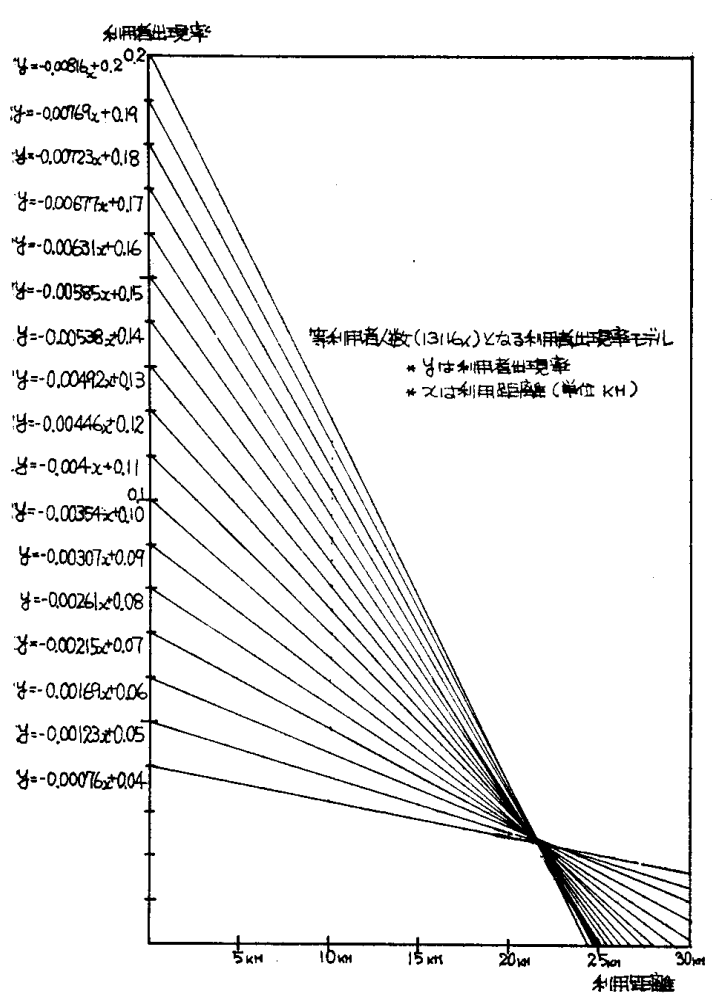

図一31 等利用者人数となる利用者出現率の变化

等が組まれる必要があると言えよう。また施設から離れ た部分の人達に利用される様な運営システムを組むこと によって利用者人数も多く，かつ利用者出現率の均等化 を計れると言える。

\section{§3. 利用率から見た施設位置の検討}

前記までの分析においては主に人口との関連で立地位 置の検討を行なったが必ずしも人口との関連のみで施設 位置を考えることが望ましいわけではなく，自然条件， 交通条件等の魅力のある場所に立地させることによって より広範囲の多くの人達が利用する（文一1 利用者分布 参照）位置に立地させることも重要と言える。ここでは それを利用率の高率化を中心に立地位置の検討を現状の 利用率の分析を中心に考察する。公立青年の家の利用率 を考える場合，宿泊，日帰りの 2 種類の利用形態がある ので宿泊は宿泊利用率を，日帰りは日㷌り利用者人数を 考える。宿泊利用率は宿泊定員に対する宿泊利用者の割 合で示せるが宿泊定員は各施設により決め方がまちまち であるので（図一32 参照）施設定員を補正して次の様 炕考える。

宿泊利用率

$$
\begin{gathered}
=\frac{\text { 宿泊利用者人数 }}{\text { 宿泊定員 }} \times \frac{\text { 施設の定員 } 1 \text { 人当り面積 }}{\text { 定員 } 1 \text { 人当り祭均面積 }} \times \text { 所数 } \\
\times 100
\end{gathered}
$$

日帰りについては定員が決められていないので年間の 日帰り利用者人数を開所日数で割り，1 日当り利用者人 数として求めた。その結果は図一33 の様に示せ, 概し て宿泊利用率の高いものは日帰り利用者人数少なく, 宿

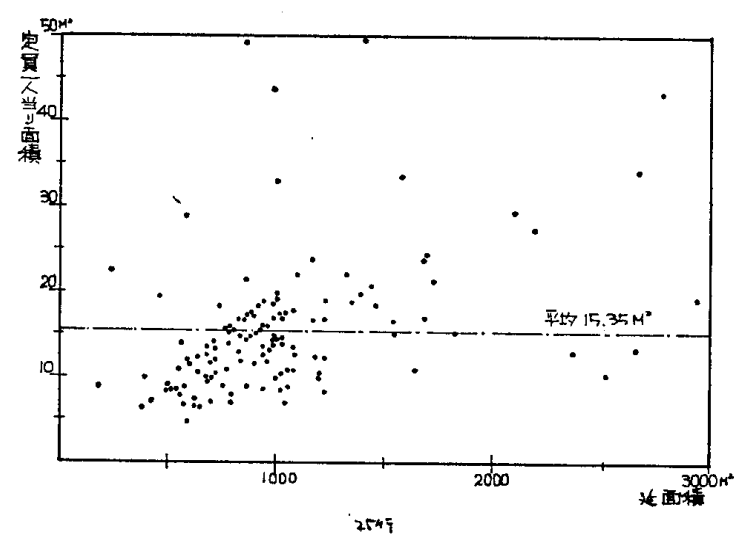

図一32 各施設の定員 1 人当り面積

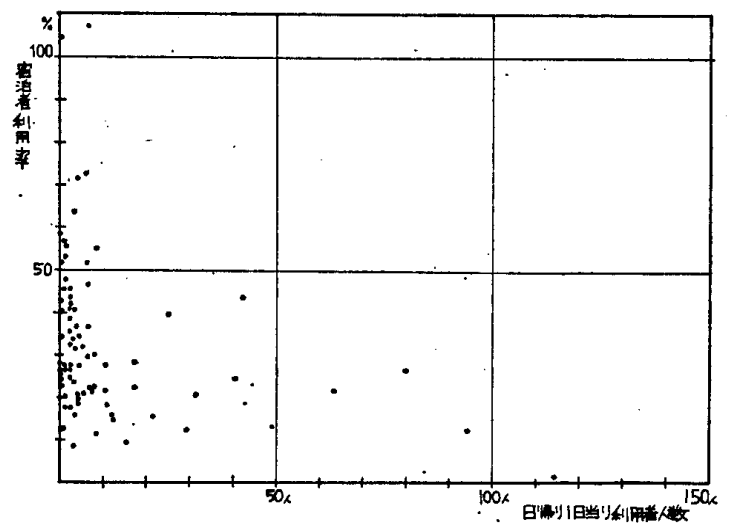

図一33 各施設の宿泊利用率と日帰り利用者人数

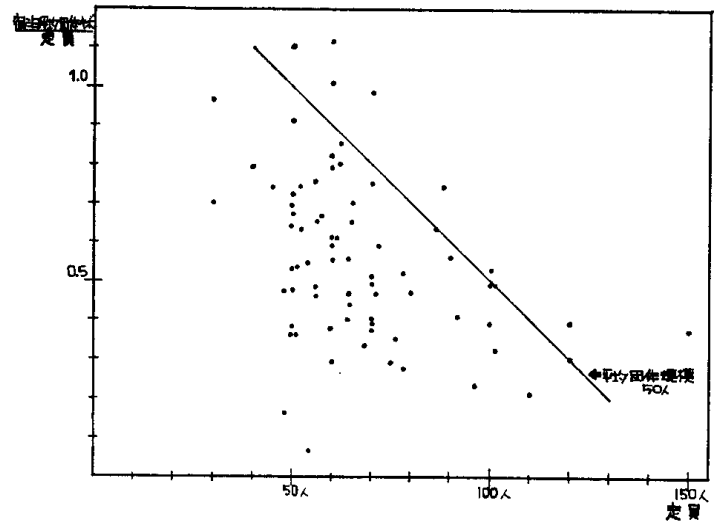

図一34 定員と宿泊団体平均規模/定員の関連

泊利用率 $20 \sim 30 \%$ で日帰り利用者人数 $0 \sim 10$ 人が最も 多く全施設の 3 割がここに入る。宿泊利用率 $100 \%$ を越 寸施設も見られるが夏季等に定員を越してテント等によ って収容する施設でこの様な方法も定員に幅を特たせる 意味で 1 つの方法と言える。

次いで幾つかの施設について利用率を施設立置ととも に見てみると表一2 の様になる。

表一2 の様に公立青年の家として高率な $50 \%$ 台施設 の資料は得られなかったが宿泊利用率 $40 \%$ 台の施設は 景勝地が多く，ユースホステル的な利用も加わってい る。しかし著名な景勝地以外はハイキング研修，スキー 研修等, ユースホステル的利用を導入しても高率になる とは言えない。40\% 台施設の日㷌り利用は多い施設で 
衰一2 公立青年の家の各施設の利用率

\begin{tabular}{|c|c|c|c|c|c|}
\hline \multirow{2}{*}{$\begin{array}{l}\text { 缩 } \\
\text { 利用事 }\end{array}$} & \multirow[b]{2}{*}{ 施 設 名 } & \multicolumn{2}{|c|}{ 各施殶の利用率 } & \multirow{2}{*}{ 宿泊定員 } & \multirow[b]{2}{*}{ 備 } \\
\hline & & $\begin{array}{l}\text { 宿 泊 } \\
\text { 利用率 }\end{array}$ & 但㽰り利| & & \\
\hline \multirow{3}{*}{$40 \%$} & $\begin{array}{l}\text { 埼玉県長潾 } \\
\text { 青年の家 }\end{array}$ & $46.1 \%$ & 6.63 人 & $100 人$ & *景勝地 \\
\hline & $\begin{array}{l}\text { 石川県金沢 } \\
\text { 市立青年の } \\
\text { 家 }\end{array}$ & $43.3 \%$ & 42.21시 & 150人 & 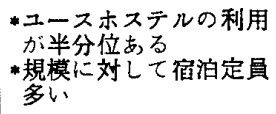 \\
\hline & $\begin{array}{l}\text { 疗木県那須 } \\
\text { 年の家 }\end{array}$ & $40.8 \%$ & 4.4 人 & 50人 & 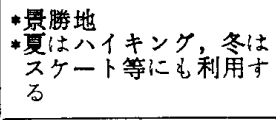 \\
\hline \multirow{5}{*}{$20 \%$} & $\begin{array}{l}\text { 荻城㽣那河 } \\
\text { 染青年の } \\
\text { 家 }\end{array}$ & $28.3 \%$ & 80.2 人 & 50人 & 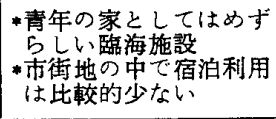 \\
\hline & $\begin{array}{l}\text { 岩手県立青 } \\
\text { 年の家 }\end{array}$ & $27.7 \%$ & 0 시 & $60 人$ & $\begin{array}{l}\text { *鹿業青年を中心とした } \\
\text { 鿬修の11の教育事么可 } \\
\text { *県を中心に各地域特有の } \\
\text { を地域課程を行っている }\end{array}$ \\
\hline & $\begin{array}{l}\text { 埼玉県東松 } \\
\text { 山神の年 }\end{array}$ & $27.3 \%$ & 7.3人 & 50 人 & \begin{tabular}{|l} 
*農業青年研修から勤労 \\
年研修へと変更
\end{tabular} \\
\hline & $\begin{array}{l}\text { 埼玉県和須 } \\
\text { 青年の家 }\end{array}$ & $21.8 \%$ & 10.57人 & 60人 & \\
\hline & $\begin{array}{l}\text { 福井市立青 } \\
\text { 年の家 }\end{array}$ & $20.9 \%$ & 31.26 人 & 50人 & $\begin{array}{l}\text { *ユースホステルとして } \\
\text { 利用㷌り研修盛ん }\end{array}$ \\
\hline \multirow{2}{*}{$10 \%$} & $\begin{array}{l}\text { 岩手県久慈 } \\
\text { 旁立青年の } \\
\text { 家 }\end{array}$ & $13.0 \%$ & 49.18人 & $50 人$ & $\begin{array}{l}\text { *日帰り研修中心で市内 } \\
\text { 怘る } \\
\text { *市外から策た人が宿泊 } \\
\text { L都市型年の家に近 } \\
\text { W }\end{array}$ \\
\hline & $\begin{array}{l}\text { 岐早県大堂 } \\
\text { 市立青年の } \\
\text { 家 }\end{array}$ & $12.4 \%$ & 94.47人 & $50 人$ & 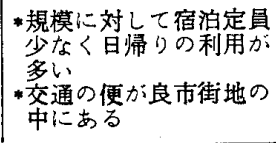 \\
\hline
\end{tabular}

1 日. 40 人平均の施設がある。これは定員が 150 人でほ とんど每日宿泊利用と日帰り利用の共用が可能であるこ とが一因と言える。宿泊利用率 $20 \%$ 台の施設で日㷌り利 用の多い施設は 1 日当り 80 人平均の利用者がある。これ は臨海施設で夏等の日帰り，宿泊利用が多いこと等によ る。宿泊利用率が低い $10 \%$ 台の施設は日帰り研修が中 心で市外から研修に来た人が宿泊する等の施設で日帰り 利用者人数は多い。以上の様に宿泊利用率を高めるには 著名な景勝地に立地させ，日帰り利用者人数を多くする には市内に立地させることが高利用率，多い利用者人数 を得る条件と言える。またこれとは別に利用率を高める には定員の適切な決め方も重要である。ちなみに図一34 を見ると定員を増加させても 1 グループ当りの規模は増 加しない。したがって平均的なグループ規模は 30〜40 人程的と考えられ，その $2 \sim 3$ 割を余裕とし見込み，そ れ以上に定員を増加させる場合には積極的に複数グルー プの同時使用を行なら観点で定員を決めることが望まし いと考えられる。

\section{§4. まとめ}

（1）日帰り研修中心 施設の 利用者出現率は 地域施 設, 広域施設に較べほぼ 10 倍程度となっている。

（2）地域施設の利用者出現率は施設に近い部分の利
用者出現率が最も高く，かつ利用者出現率の低下が急で ある。また研修内容, 運営形態によってかなり恋る。

（3）広域施設の利用者出現率は人口の分布等により 一様には低減しない。

（4）一般には利用者出現率は距離に反比例または距 離の 2 乗に反比例する。おおむね日帰り研修施設が距離 に反比例, 宿泊研修中心施設が 距離の 2 乗に 反比例す る。

（5）広域施設は施設から離れた距離の人達も利用す る様な運営が行なわれる事や距離の離れた人達も利用し たくなる様な代表的な景勝地に立地する等によって若干 均等化に近くなっている。

（6）広域施設，地域施設とも施設定員が増加すると 利用者出現率も增加する。

（7）日帰り研修中心施設，地域施設では人口がそれ ほど周辺で多くなくても利用者構成比率のピークは周辺 にある。広域施設のピークの位置は多様である。

（8）複数の施設の設置による利用者出現率のかたよ りの解消を見ると施設間距離が $20 \mathrm{~km}$ の場合は 比較的 均等化され，30 km の場合は施設間での低減が目立つ。

（9）人口との関連のみで利用者人数を計算した場 合，施設を人口中心に置いた場合が最も利用者人数が多 くなり，人口中心から離れる程低減する。

（10）人口との関連で見た場合に利用者人数の増加は 施設から離れた部分の利用者出現率が高いことが重要で ある。また施設から離れた部分の人達に利用される様な 運営システムを組むことによって利用者人数も多くかつ 利用者出現率の域等化も計れる。

(11）利用率は宿泊利用率 20 30\% で日帰り利用者 人数 1 日当り $0 \sim 10$ 人が最も多く全施設の 3 割がここに 入る。

（12）宿泊利用を高めるには代表的な景勝地に立地さ せ，日帰り利用者人数を多くするには，市内に立地させ るとよい。

（13）利用率を高めるには定員の適当な決め方も重要 である。その場合平均的なグループ規模は $30 \sim 40$ 人と 考え，その 2 3 割を余裕として見込み，それ以上の定 員の増加は積極的に複数グループの同時使用を考えるこ とが望ましい。

末筆ながら本研究にあたり東京都立大学長倉康彦助教 授の御指導に深甚の謝意を表します。また資料を提供し ていただいた各公立青年の家，文部省青少年教育課の 方々に感謝の意を表します。

\section{<関尰资料>}

文一1 公立青年の家の施設利用に関する研究(1)

・都区部青年館の使われ方に関する研究

72.9 日本建築学会論文報告集

'71.11 日本建築学会学術報告集 189 号 
STUDIES ON THERMAL WEIGHT OF THERMAL STORAGE TANKS (Part II)

Theortical Analysis for Practical Application

by YASUTAKA NAKAJIMA, Associate Prof. of Kogakuin Institute of Technology, Member of A.I.J.

In this paper, we study on the theoretical analysis for practical application of the basic one which was already reported in the part (I).

First of all, we reduce some calculating methods for the output water temperature of the thermal storage tank, using the following response coefficient of water temperature $\varepsilon$.

$$
\varepsilon=\frac{\int_{0}^{t} A^{\prime}(t-\zeta) \cdot q_{1}(\zeta) d \zeta}{P \int_{0}^{t} q_{1}(\zeta) d \zeta}
$$

These methods are (1) an accurate method by an electronic computer, (2) a method by a close approximate equation and (3) a method by calculating charts formed on diverse thermal load patterns.

Secondly, we produce the analysis for frequency response as a useful method in case that load input is expressd by frequency functions.

And last, we produce a calculating method for thermal response, and Investigate the influence of heat gain and loss of the thermal storage tank on indicial response and frequency response. Thus it is proved that insulation covering the thermal storage tank set underground is useless except upward side.

U.D.C. 725.83.011.1

AN INVESTIGATION OF PUBLIC TRAINING CENTRES FOR YOUTH (Study No. 3 on the Social Education, Welfare and Physieal Education of Youth)

(See Page 103, Transactions of the A.I.J. No. 199, Sept. 1972)

by AKIHIKO WATANABE, Graduate Student of Metro. of Tokyo Univ., Member of A.I.J.

U.D.C. $72.03: 728.3$

\section{THE STUDY OF THE SAMURAI EDO RESIDENCE IN THE EARLY MODERN ERA BY HOSOKAWA ARCHIVES}

by TAKASHI KITANO, Assistant, Kumamoto Univ., Member of A.I.J.

This paper deals with the vicissitudes of the Samurai Edo Residence in the early modern era by Hosokawa Archives.

The contents are as follows.

1. Tatsunoguchi main-residence.

2. Hosokawa Sansai's residence.

3. Shiba secondary-residence.

And in short, Hosokawa Edo residence was only Tatsunoguchi residence in 1622, and three residence existed in the site of this residence. So residence for the formal Shogunate visit could not be made. The residence for the formal Shogunate visit can be traced to the time of Kanei period.

The center of Edo residences changed secondary-residence which was broad site from main residence which was narrow site in Kanei period.

Also Sukiya residence can be traced time of Genna period. 